American Journal of Agricultural and Biological Sciences 4 (2): 137-145, 2009

ISSN 1557-4989

(C) 2009 Science Publications

\title{
Chilling Injury in Mamey Sapote Fruit (Pouteria sapota): Biochemical and Physiological Responses
}

\author{
${ }^{2}$ Guillermo O. Pérez-Tello, ${ }^{1}$ Miguel Ángel Martínez-Téllez, \\ ${ }^{1}$ Irasema Vargas-Arispuro and ${ }^{1}$ Gustavo A. González-Aguilar \\ ${ }^{1}$ Centro de Investigación en Alimentación y Desarrollo, A.C., Km 0.6, \\ Carretera a la Victoria, AP 1735, 83000, Hermosillo, Sonora, México \\ ${ }^{2}$ Instituto Tecnológico del Valle del Yaqui, Block 611, \\ Valle del Yaqui, 85000, Bácum, Sonora, México
}

\begin{abstract}
Problem statement: Cold storage is needed in order to delay senescence and achieve a longer commercial life of tropical fruits like mamey sapote (Pouteria sapota), therefore, the physiological and biochemical responses of this fruit to cold storage were evaluated. Approach: Samples from different storage temperature $\left(20,10\right.$ and $\left.2{ }^{\circ} \mathrm{C}\right)$ were taken at five-day intervals and Chilling Injury Index (CII), decay (\%), pulp firmness, weight loss (\%), sucrose, fructose and glucose contents, electrolyte leakage (\%), ethylene and carbon dioxide production rates and the activities of Peroxidase (POD), Polyphenoloxidase (PPO) and Phenylalanine Ammonia-Lyasa (PAL), were evaluated. Results: CII of fruit stored at 2 and $10^{\circ} \mathrm{C}$ was similar and symptoms included abnormal ripening into trimming zones close to the skin and pulp. Development of CI symptoms was more evident after 10 days of storage at 2 and $10^{\circ} \mathrm{C}$. This trend may be associated with decrease of sucrose content but not with fructose that increased on fruits stored at $2{ }^{\circ} \mathrm{C}(\mathrm{p}<0.05)$. For mamey fruits stored at $2^{\circ} \mathrm{C}$, the PAL activity was significant lower than in the fruits stored at $10^{\circ} \mathrm{C}$, but it did not increase in response to the chilling temperature. No appreciable changes on POD activity were observed in fruit stored at $2^{\circ} \mathrm{C}$. PPO activity continuously decreased on fruit stored at $2^{\circ} \mathrm{C}$ and similar behavior was observed on fruit stored either at 10 and $20^{\circ} \mathrm{C}$, during the first 15 days of storage. Conclusion: Our results demonstrated the sensitivity to mamey sapote fruits to low storage temperatures $\left(2\right.$ and $\left.10^{\circ} \mathrm{C}\right)$. Symptoms developed by fruit include abnormal ripening into trimming zones close to skin, as well as darkened zones into middle pulp. Sucrose content could be a better chilling injury indicator in mamey sapote than electrolyte leakage, ethylene production and POD, PPO and PAL activities.
\end{abstract}

Key words: Peroxidase, polyphenoloxidase, decay, exotic fruits, ethylene

\section{INTRODUCTION}

The demand of tropical and subtropical fruits has been increased in the last two decades due to its good sensorial characteristics and high nutrimental value. Particularly, mamey sapote (Pouteria sapota) has been considered to have great economic potential because of its typical taste and aroma ${ }^{[1]}$. However, the postharvest storage life of this kind of tropical fruits is limited by temperature exposure; therefore temperatures below $12^{\circ} \mathrm{C}$ are commonly used. Exposure of mamey fruit to temperatures below $5^{\circ} \mathrm{C}$ for more than 10 days causes Chilling Injury (CI) as indicated by dark-brown spots on the peel, failure to ripen, off-flavor development and increased decay incidence after transferring the fruit to higher temperatures ${ }^{[2]}$. There is a lack of reports regarding the causes of CI symptoms developed in mamey fruit ${ }^{[3]}$.

Under stress conditions such as cold storage, different biochemical changes are associated with fruit physiological disorders. The oxidases, peroxidases (POD; E.C.1.11.1.7), polyphenoloxidase (PPO; E.C.1.14.18.1) and the induction of phenylalanine ammonia-lyase (PAL; E.C.4.3.1.5) have been considered to be a defensive mechanism of plants against stress ${ }^{[4]}$. These enzymes have been involved in the development of physiological disorders such as CI in many vegetables ${ }^{[5]}$.

Therefore, the aim of this study was to investigate the major physiological and biochemical changes of mamey fruit during storage at chilling $\left(2\right.$ and $\left.10^{\circ} \mathrm{C}\right)$ and non-chilling $\left(20^{\circ} \mathrm{C}\right)$ temperatures.

Corresponding Author: Miguel Ángel Martínez-Téllez, Centro de Investigación en Alimentación y Desarrollo, A.C., Km. 0.6, Carretera a la Victoria, AP 1735, 83000, Hermosillo, Sonora, México Fax: +52(662) 280-04-22 
Am. J. Agri. \& Biol. Sci., 4 (2): 137-145, 2009

\section{MATERIALS AND METHODS}

Plant material and storage conditions: Mamey fruits were harvested on April 12, at the beginning of the harvest season (April-May), in an orchard cultivated in Tabasco, Mexico. Fruits were transported and maintained under controlled temperature until arrival to the laboratory, where were selected according to good appearance and freedom of defects. Fruits were separated in three groups of 80 fruits each and stored at 20,10 and $2{ }^{\circ} \mathrm{C}$ under $85-90 \% \mathrm{RH}$, during 25 days in temperature-controlled chambers. At five days intervals, 10 fruits were sampled from each storage temperature for further evaluation of the physical, physiological and enzymatic parameters during a thirtyday period. Three fruits from each temperature were removed from each group and $\mathrm{CO}_{2}$ and ethylene production were measured and then, firmness changes were determined. Afterward, remained fruit were sampled for ion leakage and sugars determination and PPO, POD and PAL activities. Three lots of 20 fruit were used to determine weight loss, evolution of CI and decay, in each temperature during the storage period. Initially, fruit were weighted and inspected for decay symptoms.

Physical and physiological evaluation: Weight loss (\%) was determined periodically as percentage of the original weight of the samples. The CII was evaluated on the subgroup of 20 fruits, using a subjective scale according to Martínez-Téllez et al. ${ }^{[6]}$, based on the browning intensity: $0=$ No pitting; $1=$ Slight (until $10 \%$ of fruit surface); 2 = Medium (until $20 \%$ of fruit surface) and $3=$ Severe pitting (more than $20 \%$ of fruit surface).

Decay was determined using a subjective scale according to Pérez-Tello et al..$^{[7]}$, considering as damage when more than $30 \%$ of the fruit surface presented an evident fungal or wooding damage. It was evaluated initially and at each interval of sampling period.

Flesh firmness was measured in three points of the equatorial zone of ten fruits per each storage temperature at each sampling period and expressed as Newtons (N) using an awl (10 mm of diameter) with a Chatillon penetrometer DFG-50 (John Chatillon Sons, Inc. USA) according to the method of Bourne ${ }^{[8]}$.

Ethylene and $\mathrm{CO}_{2}$ production rates were measured in a gas chromatograph (Varian Star 3400, MFG Corp., USA) using a TCD and FID detectors with a Haysep N column according to the method described by ${ }^{[9]}$ and expressed as $\mu \mathrm{L}$ ethylene $\mathrm{kg}^{-1} \mathrm{~h}^{-1}$ and $\mathrm{mL} \mathrm{CO}_{2} \mathrm{~kg}^{-1} \mathrm{~h}^{-1}$, respectively.
Electrolyte leakage $(\%)$ was measured from three randomly selected fruits per each group. Two pulp discs with a diameter of $1 \mathrm{~cm}$ and a thickness of $2 \mathrm{~mm}$ were excised with a cork borer from the equatorial region of the fruit. The discs were incubated with $0.3 \mathrm{M}$ mannitol for $1 \mathrm{~h}$ at ambient temperature and constant shaking. Initial electrolyte leakage was determined following incubation of each tube and final, after boiling the solution for $45 \mathrm{~min}$. Electrical conductivity of the bathing solution was measured using a conductivity meter (Mod. 1481-61, Cole-Parmer Instrument, Co, USA). Rates of ion leakage were expressed as a percentage of the total conductivity [(initial/total) $\times 100$ ].

Enzymatic assays: Acetone powder from mamey fruit was obtained from flesh of three sampled fruits stored at 2,10 and $20^{\circ} \mathrm{C}$ and stored at $-47^{\circ} \mathrm{C}$ until used for further enzyme extraction. PPO, POD and PAL activities were measured using a BioSpec 1601 spectrophotometer (Shimadzu, Japan).

The PPO (EC 1.14.18.1) activity was determined according to Pérez-Tello et al. ${ }^{[10]}$. PPO was extracted from $0.2 \mathrm{~g}$ acetone powder with a phosphate buffered saline solution, $\mathrm{pH} 7.2$, containing $1 \mathrm{M}$ potassium chloride and 5\% (w/w) polyvinyl-polypyrrolidine. Enzymatic activity was measured at $30^{\circ} \mathrm{C}$ and $410 \mathrm{~nm}$, in reaction mixtures with $1.25 \mathrm{~mL}$ of $20 \mathrm{mM} 4-$ methylcatechol as substrate and $25 \mu \mathrm{L}$ of the enzyme extract. PPO activity was expressed on a dry matter basis as units of PPO g ${ }^{-1} \mathrm{~min}^{-1}$ of acetone powdered flesh tissue.

POD (EC 1.11.1.7) activity was determined using a modified method of Pérez-Tello et al. ${ }^{[10]}$. The enzyme was extracted from $0.2 \mathrm{~g}$ of acetone powder from flesh tissue with $6 \mathrm{~mL}$ of $100 \mathrm{mM}$ Tris- $\mathrm{HCl}, \mathrm{pH} 8.0$, containing $5 \mathrm{mM} \beta$-mercaptoethanol and $5 \%(\mathrm{w} / \mathrm{w})$ polyvinyl-polypyrrolidine. POD activity was measured at $470 \mathrm{~nm}$ for $2 \mathrm{~min}$ at $30^{\circ} \mathrm{C}$ in $2.15 \mathrm{~mL}$ reaction mixtures with $10 \mathrm{mM}$ sodium acetate, $\mathrm{pH} 5.3$, containing $0.5 \%$ of the substrate guaiacol, $0.25 \mathrm{~mL} 0.1 \%$ hydrogen peroxide and $100 \mu \mathrm{L}$ extract. POD activity was expressed on a dry matter basis as units of activity $\mathrm{g}^{-1}$ of acetone powered flesh tissue $\min ^{-1}\left(\mathrm{U} \mathrm{g}^{-1} \mathrm{~min}^{-1}\right)$.

PAL (EC 4.3.1.5) activity ( $\mathrm{mol} \mathrm{g} \mathrm{g}^{-1} \mathrm{~h}^{-1}$ ) was determined according to Martínez-Téllez and Lafuente ${ }^{[11]}$. PAL was extracted from $0.4 \mathrm{~g}$ of acetone powder with $15 \mathrm{~mL}$ of $100 \mathrm{mM}$ sodium borate, $\mathrm{pH} 8.8$, containing $20 \mathrm{mM} \beta$-mercaptoethanol. Proteins were salted out with ammonium sulphate to a final saturation of $46 \%$ and thereafter dissolved in $4.5 \mathrm{~mL}$ of $100 \mathrm{mM}$ ammonium acetate, $\mathrm{pH} 7.7$, containing $20 \mathrm{mM} \beta$ mercaptoethanol. The reaction mixtures contained $2 \mathrm{~mL}$ 
of the purified enzyme extract and $0.6 \mathrm{~mL}$ of $100 \mathrm{mM}$ L-phenylalanine in a final volume of $6 \mathrm{~mL}$. PAL activity was determined by measuring the absorbance of cinnamic acid at $290 \mathrm{~nm}$ for $2 \mathrm{~h}$ at $40^{\circ} \mathrm{C}$ and expressed on a dry matter basis as nmol of cinnamic acid $\mathrm{g}^{-1}$ of acetone powder fresh tissue $\mathrm{h}^{-1}\left(\mathrm{n} \mathrm{mol} \mathrm{g}^{-1} \mathrm{~h}^{-1}\right)$.

Sugars determination: Sucrose, glucose and fructose contents were quantified according to a modification of the HPLC procedure described in Hunt et al. ${ }^{[12]}$ and López-Hernández et $a l^{[13]}$. Sucrose, glucose and fructose, were initially extracted from $10 \mathrm{~g}$ of flesh fruit stored at 2,10 and $20^{\circ} \mathrm{C}$, with $50 \mathrm{~mL}$ of HPLC grade water and boiled for $15 \mathrm{~min}$. The solution was diluted in HPLC grade water (1:20, v/v), filtered in Wahtman paper No. 40 and separated by ultracentrifugation (Beckman, Co.) at $4500 \mathrm{rpm}$. Supernatants were filtered through nylon GV membranes (Millipore, Co.) into a glass syringe and the extracts were injected in an HPLC equipment (Varian 9012, USA). Mobile phase was acetonitrile-water $(80: 20)$ at $192 \mathrm{~nm}$ in the UV region using an UV-VIS detector (Varian 9050, USA) and $\mu$ $\mathrm{NH}_{2}$ Bondapak column $(3.9 \times 300 \mathrm{~mm} ; 10 \mathrm{~mm}$ of particle size) and a flow rate of $1.5 \mathrm{~mL} \min ^{-1[12]}$. Quantitative determinations were made by comparing the sample analyses results of three fruit extracts with the standard mixture of sugars prepared by dilution of $4 \% \mathrm{w} / \mathrm{v}$ solutions of reagent grade in HPLC grade water and expressed as $\mathrm{mg} \mathrm{g}^{-1}$ Fresh Weight (FW).

Statistical analysis: Statistical analysis of the experimental data were done according to a completely randomized design with three replications by performing ANOVA tests and comparisons of means with the main factors, using the Tukey-Kramer test $(\alpha=5 \%)$. The treatments were the time and storage temperatures. The data obtained were analyzed using NCSS (6.0.22 version) and Sigma Plot (8.0 version) computer packages.

\section{RESULTS}

Physical and physiological evaluation: Figure 1 shows the Chilling Injury (CI), Weight Loss (WL), firmness and decay of mamey fruits during storage at 2 , 10 and $20^{\circ} \mathrm{C}$. The highest WL was observed on fruits stored at $20^{\circ} \mathrm{C}$, which increased significantly within the storage period. No significant differences in weight loss were observed in fruits stored at 2 and $10^{\circ} \mathrm{C}$. The highest firmness loss was observed after 5, 10 and 15 days in fruits stored at 20,10 and $2^{\circ} \mathrm{C}$, respectively. Fruit firmness decreased constantly with the storage period but at different extent. After five days of storage, fruits stored at $20^{\circ} \mathrm{C}$ reduced their firmness from 150-30 N. Afterward, it decreased to values of $10 \mathrm{~N}$ and was maintained relatively constant with values slightly lower than those fruits stored at $10^{\circ} \mathrm{C}$ (Fig 1a and b).

CII significantly increased either on fruits stored at 10 and $2{ }^{\circ} \mathrm{C}$ after 10 days of storage with a similar damage pattern in both treatments, reaching the maximum CI value (1.7) after 20 days of storage. As expected, no symptoms of CI were observed on fruits stored at $20^{\circ} \mathrm{C}$ (Fig 1c). Even though the CII was similar on fruits stored at 10 and $2^{\circ} \mathrm{C}$, apparently fruits stored at $2{ }^{\circ} \mathrm{C}$ developed other physiological disorders that significantly affected deterioration of fruit measured as percentage of decay (Fig 1d). After 10 days of storage decay of fruit was close to $20 \%$, being more evident on fruit stored at 2 and $20^{\circ} \mathrm{C}$ that presented similar percentage of decay. Deterioration of fruit stored at $10^{\circ} \mathrm{C}$ was lower than that observed at 2 and $20^{\circ} \mathrm{C}$ and started to increase after 15 days of storage (Fig 1d).

In general, fruit metabolism is enhanced by the rise of storage temperature, while maturation of chillingsensitive fruit could be seriously affected by low temperature storage. In this matter, we observed that fruits stored at $20^{\circ} \mathrm{C}$ matured normally, in contrast with fruits stored at 2 and $10^{\circ} \mathrm{C}$ which presented different CI symptoms and abnormal maturation (Fig 1c).

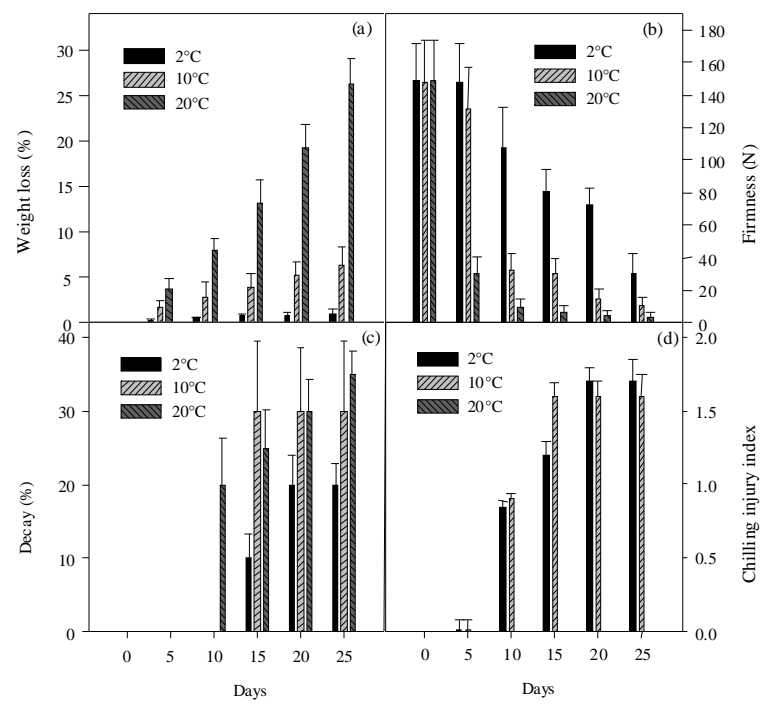

Fig. 1: Weight Loss (a): Firmness; (b): Decay; (c): Chilling Injury Index (CII); (d): In mamey fruits stored at 2,10 and $20^{\circ} \mathrm{C},(80-90 \% \mathrm{RH})$ 
Development of decay symptoms started after 10 days of storage in fruits stored at $20^{\circ} \mathrm{C}$ (Fig 1c). Afterwards, a sharp increase in the percentage of decay (30\%) was observed on fruit stored either at 2 and $20^{\circ} \mathrm{C}$. After 25 days of storage, about $50 \%$ of the fruits stored at 2 and $10^{\circ} \mathrm{C}$ showed severe CI symptoms in the pulp (grade 3), caused mainly by abnormal flesh ripening and darkening. Some of these symptoms could be due to some metabolic disruptions that occur at low temperatures.

At the end of storage, most of the fruits stored at $20^{\circ} \mathrm{C}$ were invaded by green mold but in different extent. The high content of carbohydrates, lipids and water in the pulp, could induce mold growth near to peduncle and affect overall quality of fruits stored at 20 and $10^{\circ} \mathrm{C}$.

The $\mathrm{CO}_{2}$ and ethylene production are shown in Fig. 2. The behavior observed for $\mathrm{CO}_{2}$ production in fruits stored at 20 and $10^{\circ} \mathrm{C}$ showed a similar pattern until day 25 of storage (Fig 2a). Also, the $\mathrm{CO}_{2}$ production rate in control fruits $\left(20^{\circ} \mathrm{C}\right)$ decreased during the first 15 days of storage and remained without significant changes. However, after five days, fruits stored at lower temperatures presented a significant decrease in $\mathrm{CO}_{2}$ production, from 155$25 \mathrm{~mL} \mathrm{CO} \mathrm{kg}^{-1} \mathrm{~h}^{-1}$. Afterward, $\mathrm{CO}_{2}$ production kept gradually decreasing until it reached the lowest values $\left(5-11 \mathrm{~mL} \mathrm{~kg}^{-1} \mathrm{~h}^{-1}\right)$ at the end of the storage period. No significant differences on respiration rate were observed in fruits stored at 2 and $10^{\circ} \mathrm{C}$.

The highest ethylene production was observed initially (Fig 2b). Afterwards, ethylene production significantly decreased with the storage period. A similar behavior was observed for ethylene production. After five days of storage, a sharp reduction in ethylene production was observed in fruits stored either at 2, 10 and $20^{\circ} \mathrm{C}$. Afterward, ethylene was maintained stable with slight changes on fruits stored at $2^{\circ} \mathrm{C}$. The lowest ethylene production was observed after 15 days on fruits stored at $20^{\circ} \mathrm{C}$. No ethylene was detected after 25 days.

Electrolyte leakage: A noticeable increase in electrolyte leakage was observed in all storage temperatures $\left(2,10\right.$ and $\left.20^{\circ} \mathrm{C}\right)$ after five days of fruit exposure, reaching an almost two-fold increment by day 25 (Fig 2c). The increase trend of electrolyte leakage could be associated with the invasion of mold (decay) at 10 and $20^{\circ} \mathrm{C}$, chilling symptoms at 2 and $10^{\circ} \mathrm{C}$ or may also have caused altered ripening and senescence processes at $20^{\circ} \mathrm{C}$ as sown in Fig $1 \mathrm{c}$ and $1 \mathrm{~d}$. Loss of cell integrity by senescence was more accentuated at 20 and $10^{\circ} \mathrm{C}$ than at $2{ }^{\circ} \mathrm{C}$, causing an increase of electrolyte leakage. The trend of electrolyte leakage at $10^{\circ} \mathrm{C}$ showed a similar behavior to the group stored at $20^{\circ} \mathrm{C}$ along the 25 days of storage.

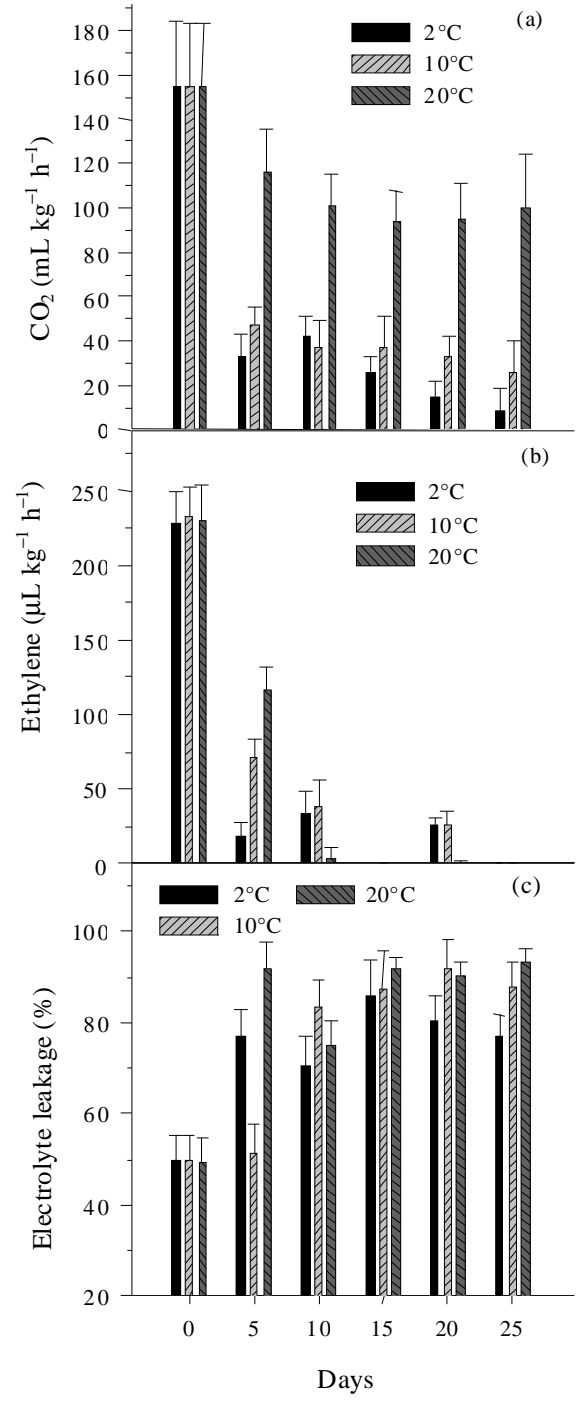

Fig. 2: $\mathrm{CO}_{2}$ production; (a): Ethylene production; (b): Electrolyte leakage; (c): In mamey fruits stored at 2,10 and $20^{\circ} \mathrm{C},(80-90 \% \mathrm{RH})$

Enzyme assays: In this research PAL activity was detected, but showing low values along the 25 days of storage in the three groups of fruits (Fig 3a). PAL activity was higher after five days of storage at 10 and $20^{\circ} \mathrm{C}$ and decreased along the further 10 days of storage. Moreover, PAL activity increased after 15 and 25 days of storage. Fruits stored at $10^{\circ} \mathrm{C}$ showed an initial decrease in PAL activity between days 5 and 25 and then a slowly increase was observed after 25 days. For mamey fruits stored at $2^{\circ} \mathrm{C}$, the PAL activity was significant minor with respect to the fruits stored at $10^{\circ} \mathrm{C}$, but it did not increase in response to the chilling temperature. Such low levels of PAL activity in those fruits could be a result of the age and harvest date. 


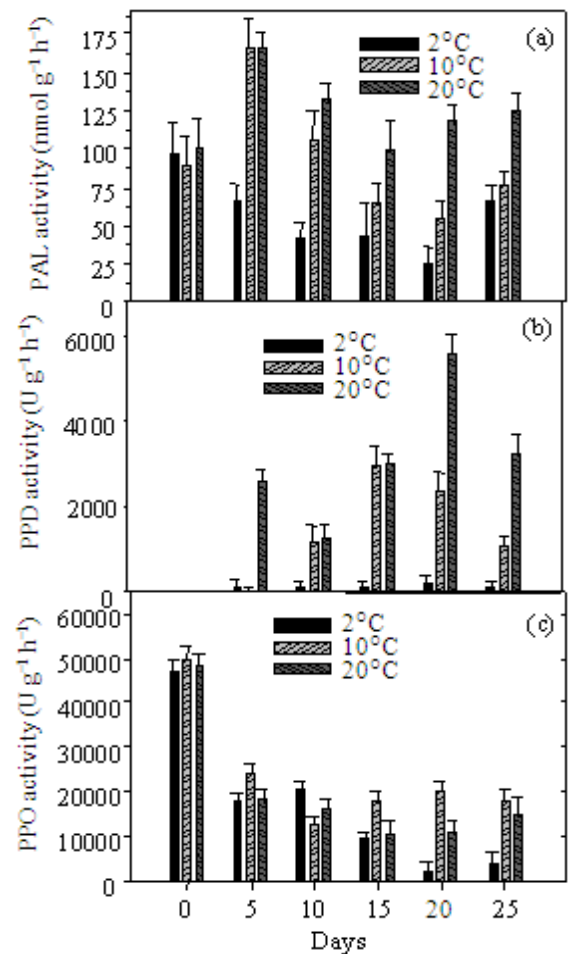

Fig. 3: POD activity; (a): PPO activity; (b): PAL activity; (c): In mamey fruits stored at 2, 10 and $20^{\circ} \mathrm{C},(80-90 \% \mathrm{RH})$

Mamey fruits used in this work were collected at the beginning of the harvest season (April 12), thereby the magnitude of these responses was not indicative of the chilling susceptibility degree of this specific cultivar.

In this study the initial POD activity was negligent and not detected (Fig 3b). However, POD activity increased with temperature and storage period. The highest POD activity was observed in fruits exposed at $20^{\circ} \mathrm{C}$ after 20 days of storage, followed by those stored at $10^{\circ} \mathrm{C}$. POD activity levels in fruits stored at $2^{\circ} \mathrm{C}$ was very low during all storage period. After five days at $20^{\circ} \mathrm{C}$, a sharp increase on POD activity was observed with respect to other temperatures. However at $10^{\circ} \mathrm{C}$ the maximum POD activity (3000 U) of fruits was reached after 15 days and then it decreased reaching a value of $1000 \mathrm{U}$ after 25 days of storage. In this research, there were not observed appreciable changes in POD activity in fruit stored at $2^{\circ} \mathrm{C}$.

The arise on POD activity was correlated with the deterioration of fruits stored at 10 and $20^{\circ} \mathrm{C}$ but not with the CI symptoms observed in those fruits stored at 2 C. PPO activity continuously decreased (48332$15151 \mathrm{U}$ ) on fruits stored at $2^{\circ} \mathrm{C}$ (Fig. 3c). Similar behavior was observed on fruits stored either at 10 and $20^{\circ} \mathrm{C}$, during the first 15 days of storage. Afterwards,

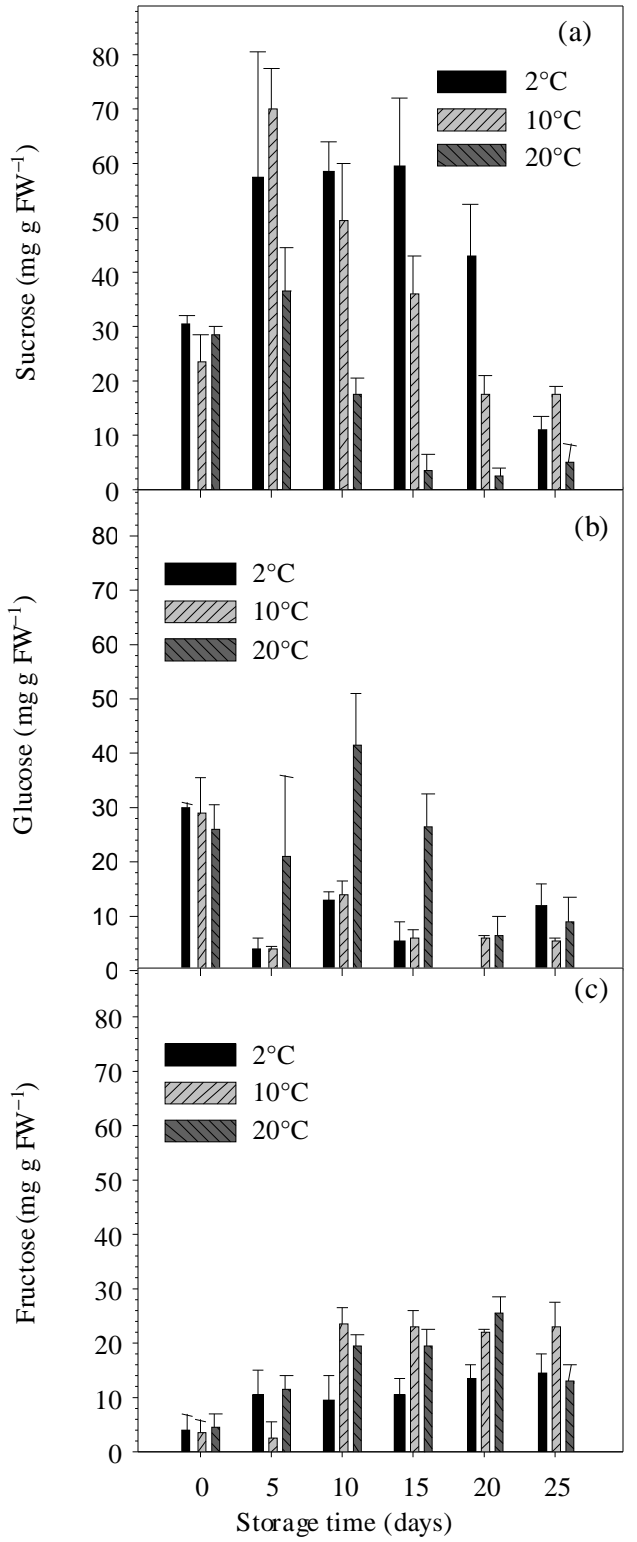

Fig. 4: Sucrose (a): Glucose (b): Fructose content (c): In mamey fruits stored at 2,10 and $20^{\circ} \mathrm{C},(80-$ $90 \% \mathrm{RH})$

PPO activity was maintained stable until the end of the storage period. Even when PPO and POD are involved in deteriorative processes of tissue such as browning, activity of both enzymes could vary depending upon the fruit, cultivar and storage conditions.

Carbohydrates content: The pattern of changes in soluble carbohydrates of fresh mamey sapote stored at 2, 10 and $20^{\circ} \mathrm{C}$ are shown in Fig. 4. The major carbohydrate detected in all samples was sucrose, 
followed by glucose and fructose. Sucrose content of mamey sapote decreased during storage at $20^{\circ} \mathrm{C}$ (Fig. 4a), where the highest sucrose level in this group was observed on the 5th day, with a 1.2-fold increase. However, fruits stored at $10^{\circ} \mathrm{C}$ reached the highest sucrose level after five days of storage, showing a 3fold increase of this carbohydrate. Fruits stored at $2^{\circ} \mathrm{C}$ showed a constant value in sucrose content between days 5-15; a further decline was observed from day 20th onwards. A significant and uniform decrease of sucrose content was observed in fruits stored at $10^{\circ} \mathrm{C}$ along the last three sampling periods (days 10, 15 and 20). Glucose levels of fruits stored at $20^{\circ} \mathrm{C}$ increased after 10 days and further decreased between days 15 and 20 of storage as shown in Fig 4b. The increase of glucose was probably due to sucrose degradation by invertase into glucose and fructose, which may be a more useful form for fruit respiration. Glucose content showed an initial 7.2-fold decrease in fruits stored at 10 and $2^{\circ} \mathrm{C}$ and kept a similar behavior from days $5-25$, while the highest value of glucose levels was reached by fruits stored at $2^{\circ} \mathrm{C}$ after 10 days of storage (Fig. 4b).

Fructose content increased along with the storage time in fruits stored at $20^{\circ} \mathrm{C}$; the maturity and senescence processes can be related to this event. Fructose content showed a similar pattern at 10 and $2^{\circ} \mathrm{C}$, but it was higher at $10^{\circ} \mathrm{C}$ during the 25 days of storage (Fig. 4c). The trend of fructose content at $2^{\circ} \mathrm{C}$ showed a similar behavior than the group stored at $10^{\circ} \mathrm{C}$; this occurrence could be attributed to a response to chilling stress.

\section{DISCUSSION}

It has been reported that firmness of tropical fruits decreased during ripening and senescence processes ${ }^{[2]}$. Different enzymes are involved in the firmness reduction of flesh tissue and their activity increase along with increases in storage temperature. Therefore, it is expected that fruits stored at higher temperatures had the highest firmness and weight losses as observed in the present study. Firmness could be an important physical indicator for mamey fruit quality. However, the firmness evaluation on mamey sapote pulp, necessarily involves a destructive technique and the major problem of mamey fruit is the variation in fruit maturation. Recently, it has been reported that a nondestructive technique such as vibration, may be useful to detect slight changes in firmness of tomatoes treated with methyl jasmonate and stored at different temperatures ${ }^{[14]}$. This technique could be used as an alternative to evaluate mamey firmness. However further studies are needed in order to demonstrate the advantages that offer these techniques in this type of fruit.

Tropical fruit normally develop chilling injury symptoms below $10^{\circ} \mathrm{C}$. Results obtained in the present study, confirmed those obtained previously in Mamey sapote where CI symptoms were observed on fruit stored at $10^{\circ} \mathrm{C}^{[15]}$. Nevertheless, other authors reported that lower temperatures $\left(5^{\circ} \mathrm{C}\right)$ develop this physiological disorder in this tropical fruit ${ }^{[6]}$. In this study we observed that fruits stored at 2 and $10^{\circ} \mathrm{C}$ presented similar patterns of CI symptoms development. However, mamey fruits stored at $12^{\circ} \mathrm{C}$ did not show chilling injury development ${ }^{[16]}$. These results confirmed that storage duration and temperature are critical factors for CI development in sensitive fruits.

Respiration rate of mamey fruit could be influenced by different factors such as cultivar, storage temperature among others. Kader reported a $\mathrm{CO}_{2}$ production between 25 and $35 \mathrm{~mL} \mathrm{~kg}^{-1} \mathrm{~h}^{-1}$ in mamey sapote stored at $20^{\circ} \mathrm{C}^{[2]}$. Our data contrast with data reported by this author, but nevertheless the $\mathrm{CO}_{2}$ production observed in this study was similar to an earlier study on Mexican mamey sapote stored during 30 days at $20^{\circ} \mathrm{C} \quad\left(90-137 \quad \mathrm{~mL} \quad \mathrm{CO}_{2} \quad \mathrm{~kg}^{-1} \mathrm{~h}^{-1}\right)^{[17]}$. Alia et al. ${ }^{[15]}$ reported a $\mathrm{CO}_{2}$ production of $25-85 \mathrm{~mL}$ $\mathrm{kg}^{-1} \mathrm{~h}^{-1}$ during 12 days of storage at $20^{\circ} \mathrm{C}$. These authors reported that mamey fruit had the maximum climacteric peak $\left(85.3 \mathrm{~mL} \mathrm{CO} \mathrm{kg}^{-1} \mathrm{~h}^{-1}\right) 8$ days after harvest. However, in the present study fruit stored at $20^{\circ} \mathrm{C}$ did not present any peak during storage and followed a pattern similar to those fruits stored at 2 and $10^{\circ} \mathrm{C}$.

Ethylene affects maturation processes and can be stimulated by different stresses such as low and high temperature storage. The slight increase of ethylene observed in fruits stored at 2 and $10^{\circ} \mathrm{C}$ after 10 and 20 days, could be associated with the CI development. Alia et al. ${ }^{[15]}$ reported that mamey fruit stored at 5 and $10^{\circ} \mathrm{C}$ and then transferred at $20^{\circ} \mathrm{C}$, increased the $\mathrm{CO}_{2}$ and ethylene production as a consequence of cold stress, which was associated with the incidence of CI symptoms. Citrus fruit stored at $2^{\circ} \mathrm{C}$, also presented an increased ethylene production as response to cold storage of chilling sensitive mandarins ${ }^{[18]}$. Although the respiratory responses of many commodities and tissues have been related to chilling temperatures, the course and rate of respiration are not uniform among these commodities and tissues ${ }^{[19]}$. In some commodities ethylene production is stimulated during chilling; in others, ethylene production does not occur until chilled tissues are transferred to a warmer non-chilling temperature ${ }^{[19]}$. The results in this work, suggest that ethylene production is not a good indicator of chilling 
injury in mamey sapote stored at 2 or $10^{\circ} \mathrm{C}$. However, it appears that fruits used in the present experiment had a higher metabolic rate than those used previously.

Despite electrolyte leakage has been established as a parameter to evaluate chilling injury ${ }^{[20,21]}$, the results in this study varied significantly (Fig 2c). Therefore, a conclusion regarding tissue damage in mamey fruits cannot be drawn from this parameter.

PAL activity is a key enzyme of secondary metabolism, expressed as a defense mechanism in response to different stresses. In 'Fortune' mandarins fruits, PAL activity could be a protective response of the fruit to repair the damage originated by chilling ${ }^{[22]}$. It was observed that PAL activity was higher in mamey fruit after five days of storage at 10 and $20^{\circ} \mathrm{C}$ and decreased along the further 10 days of storage. Moreover, PAL activity increased after 15 and 25 days of storage. This behavior at $20^{\circ} \mathrm{C}$ probably indicates a physiological response to fruit senescence and to mold attack by regulating the defense mechanisms. Fruits stored at $10^{\circ} \mathrm{C}$ showed an initial decrease in PAL activity between days 5 and 25 and then a slowly increase was observed after 25 days. Probably PAL enzyme was activated by chilling at $10^{\circ} \mathrm{C}$ at the middle of storage and inhibited at the beginning ${ }^{[23,24]}$.

Studies in Fortune mandarins have indicated that the effect of cold stress in increasing PAL activity was clearly higher in fruit harvested in February $\left(1400 \mathrm{n} \mathrm{mol} \mathrm{g}^{-1} \mathrm{~h}^{-1}\right)$ than in those harvested in January $\left(400 \mathrm{n} \mathrm{mol} \mathrm{g}^{-1} \mathrm{~h}^{-1}\right)^{[25]}$.

With these results we concluded that PAL activity was not a good biochemical marker for chilling susceptibility in mamey sapote fruits.

POD and PPO activities play an important roll in the oxidative degradation of phenolic compounds, as they lead the production of brown polymers ${ }^{[26]}$. Fruit stored at $10^{\circ} \mathrm{C}$ reached its maximum POD activity (3000 U) after 15 days and then it decreased reaching a value of $1000 \mathrm{U}$ after 25 days of storage. These values are in accordance with previous studies in mamey fruit that reported a POD activity of 1600 U-POD $\mathrm{g}^{-1[15]}$. These authors reported a maximum POD activity of $2400 \mathrm{U} \mathrm{g}^{-1}$, after 25 days at $10^{\circ} \mathrm{C}$. In this research, no appreciable changes in POD activity in fruit stored at $2^{\circ} \mathrm{C}$ were observed.

The arise on POD activity was correlated with the deterioration of fruits stored at 10 and $20^{\circ} \mathrm{C}$ but not with the CI symptoms observed in those fruits stored at $2 \mathrm{C}$. In previous studies on mamey sapote fruit, the high POD activity was related with the CI development observed at the end of storage ${ }^{[27]}$. Some authors mentioned a relationship between POD activity and some physiological disorders in vegetables ${ }^{[4,5]}$.
However, storage of fruit at chilling temperature $\left(2^{\circ} \mathrm{C}\right)$ did not show to induce a significant increase in POD activity along the 25 days of storage. The increase in POD activity detected in fruits stored at 10 and $20^{\circ} \mathrm{C}$, could be influenced by the observed accelerated metabolism and decay.

Even when PPO and POD are involved in deteriorative processes of tissue such as browning, activity of both enzymes could vary depending upon the fruit, cultivar and storage conditions. Previous results suggest that POD activity was inhibited in pulp of mamey fruits chilled at $2^{\circ} \mathrm{C}$, while PPO activity was not affected $^{[27]}$.

It has been shown that increased resistance to $\mathrm{CI}$ is strongly associated with the carbohydrate content ${ }^{[28,29]}$. A significant and uniform decrease of sucrose content was observed in fruits stored at $10^{\circ} \mathrm{C}$ along the last three periods of sampling (days 10, 15 and 20). The relative increase in sucrose content at 2 and $10^{\circ} \mathrm{C}$ in the first period of storage (day five) could be attributed to a physiological response of tissues to chilling injury ${ }^{[30,31]}$. The trend of fructose content at $2^{\circ} \mathrm{C}$ showed a similar behavior than the group stored at $10^{\circ} \mathrm{C}$; this occurrence could be attributed to a response to chilling stress. Nevertheless, the relationship between chilling injury and content of sucrose, fructose and soluble sugars varies respect the fruit and is not clear yet.

\section{CONCLUSION}

Our results demonstrated the chilling sensitivity of mamey sapote fruits to storage temperatures of 2 and $10^{\circ} \mathrm{C}$. Symptoms developed by fruit included abnormal ripening into trimming zones close to skin, as well as darkened zones into middle pulp. The lower the storage temperature the higher the chilling injury symptoms. Fruit sucrose content increased as the temperature storage decreased. Ethylene production and electrolyte leakage were not correlated with the chilling injury symptoms under our experimental conditions. Enzymatic activities of POD, PPO and PAL in mamey sapote fruits stored at 2 and $10^{\circ} \mathrm{C}$ changed in different extent and were not correlated with the other evaluated variables. According to previous studies, it is difficult to establish a good biochemical indicator of chilling injury, due to the intrinsic physiological characteristics of mamey fruit. Therefore additional studies are needed in order to elucidate the possible mechanism by which chilling injury occurs in mamey sapote fruit.

\section{ACKNOWLEDGEMENT}

Thanks to Olivia Briceño and Brenda Espinoza for technical assistance and to Emmanuel Aispuro for technical assistance and review of the manuscript. 


\section{REFERENCES}

1. Díaz-Pérez, J.C., S. Bautista, R. Villanueva and R. López-Gómez, 2003. Modeling the ripening of mamey (Pouteria sapota (Jacq.) H.E. Moore and Stearn) fruit at various temperatures. Postharvest Biol. Technol., 28: 199-202.

http://cat.inist.fr/?aModele $=$ afficheN\&cpsidt $=14668$ 128

2. Kader, A.A., 2006. Sapotes: (sapodilla and mamey sapote), recommendations for maintaining postharvest quality. University of California-Davis, USA.

http://postharvest.ucdavis.edu/Produce/ProduceFac ts/Fruit/sapotes.shtml

3. Díaz-Pérez, J.C., S. Bautista and R. Villanueva, 2000. Quality changes in sapote mamey fruit during ripening. Postharvest Biol. Technol., 18: 68-73. http://cat.inist.fr/?aModele $=$ afficheN\&cpsidt $=1533$ 131

4. Robinson, D.S., 1991. Peroxidases and their Significance in Fruit and Vegetables. In: Food Enzymology, Fox, P.F. (Ed.). Elsevier Science Publishers, London, UK., ISBN: 10: 185166615X, pp: 399-426.

5. Vamos-Vigyázó, L., 1981. Polyphenol oxidase and peroxidase in fruits and vegetables. Crit. Rev. Food Sci. Nutr., 15: 49-127. http://www.ncbi.nlm.nih.gov/pubmed/6794984

6. Martínez-Téllez, M.A., M.G. Ramos-Clamont, A.A. Gardea and I. Vargas-Arispuro, 2002. Effect of infiltrated polyamines on polygalacturonase activity and chilling injury responses in zucchini squash (Cucurbita pepo L.). Biochem. Biophys. Res. Commun., 295: 98-101. DOI: 10.1016/S0006291X(02)00631-9

7. Pérez-Tello, G.O., B.A. Silva-Espinoza, I. VargasArispuro, B.O. Briceño-Torres and M.A. MartínezTéllez, 2001. Effect of Temperature on Enzymatic and Physiological Factors Related to Chilling Injury in Carambola Fruit (Averrhoa carambola L.). Biochem. Biophys. Res. Commun., 287: 846-851. DOI: $10.1006 /$ bbrc.2001.5670

8. Bourne, M.C., 1980. Texture evaluation of horticultural crops. HortSci., 15: 51-57. http://www.fao.org/agris/search/display.do?f=./198 1/v703/US8002088.xml;US8002088

9. Ward, T., M. Wright, J. Roberts, R. Self and D. Osborne, 1978. Analytical Procedures for the Assay and Identification of Ethylene. In: Isolation of Plant Growth Substances, Hillman, J. (Ed.). Cambridge University Press, Cambridge, UK., ISBN: 10: 0521218667, pp: 135-151.
10. Pérez-Tello, G.O., B.A. Silva-Espinoza, I. VargasArispuro, B.O. Briceno-Torres and M.A. MartinezTellez, 2001. Effect of temperature on enzymatic and physiological factors related to chilling injury in Carambola fruit (Averrhoa carambola L.). Biochem. Biophys. Res. Commun., 287: 846-851. http://www.ncbi.nlm.nih.gov/pubmed/11573941

11. Martínez-Téllez, M.A. and M.T. Lafuente, 1997. Effect of high temperature conditioning on ethylene, phenylalanine ammonia-lyase, peroxidase and polyphenol oxidase activities in flavedo of chilled "fortune" mandarin fruit. J. Plant Physiol., 150: 674-678. http://cat.inist.fr/?aModele $=$ afficheN\&cpsidt $=2110631$

12. Hunt, R.S, P.A. Jackson, R.E. Mortlock and R.S. Kirtc, 1977. Quantitative determination of sugars in foodstuff by high-performance liquid chromatography. Analyst, 102: 917-920. DOI: 10.1039/AN9770200917

13. López-Hernández, J., C.M.E. González, B.M.L. Vázquez, O. Vázquez and L. Simal, 1994. HPLC determination of sugars and starch in green beans. J. Food Sci., 59: 1048-1050. DOI: 10.1111/j.1365-2621.1994.tb08186.x

14. Baltazar, A., J. Espina-Lucero, I. Ramos-Torres and G. González-Aguilar, 2007. Effect of methyl jasmonate on properties of intact tomato fruit monitored with destructive and nondestructive tests. J. Food Eng., 80: 1086-1095. DOI: 10.1016/j.jfoodeng.2006.09.001

15. Alia-Tejacal, I., M.T. Colinas-León, M.T. MartínezDamián and R.M. Soto Hernández, 2005. Chilling injury in sapote mamey (Pouteria sapota (Jacq.) H.E. Moore and Stearn). I. Changes in volátiles, firmness and total sugars. Rev. Fitotec. Mex., 28: 17-24.

http://www.cababstractsplus.org/abstracts/Abstract. aspx?AcNo=20053085828

16. Martínez, M.A., T.I. Alia and L.M.T. Colinas, 2006. Refrigeración de frutos de zapote mamey (Pouteria sapota (Jac.) H.E. Moore and Stearn) cosechados en diferentes fechas en Tabasco, México. Rev. Fitotec. Mex., 29: 51-57. http://redalyc.uaemex.mx/redalyc/src/inicio/ArtPdf Red.jsp?iCve=61009809

17. Muharrem, E., S. Sargenta, A. Foxa, J.H. Craneb and D. Hubera, 2005. Ripening and quality responses of mamey sapote fruit to postharvest wax and 1-methylcyclopropene treatments. Postharvest Biol. Tecnol., 36-2: 127-134. DOI: 10.1016/j.physletb.2003.10.071 
18. Lafuente, M.T., L. Zacarias, M.A. Martínez-Téllez, M.T. Sanchez-Ballesta and E. Dupille, 2001. Phenylalanine ammonia-lyase as related to ethylene in the development of chilling symptoms during cold storage of citrus fruits. J. Agric. Food Chem., 49: 6020-6025. DOI: 10.1021/jf010790b

19. Paull, R.E. and J.W. Armstrong, 1994. Insect Pest and Fresh Horticultural Products: Treatments and Responses. CAB International, Oxford, UK., pp: 197-200.

20. Fuchs, Y., G.R. Zauberman and A. Weksler, 1989. Chilling injury and electrolyte leakage in cold stored mango and avocado fruits. Acta Hortic., 258: 612-616.

http://www.actahort.org/books/258/258_34.htm

21. Saltveit, M.E. 1991. Prior temperature exposure affects subsequent chilling sensitivity. Physiol. Plant., 82-4: 483-650. DOI: 10.1111/j.13993054.1991.tb02943.x.

22. Lafuente, M.T., L. Zacarias, M.A. Martínez-Téllez, M.T. Sánchez-Ballesta and E. Dupille, 2001. Phenylalanine ammonialyase as related to ethylene in the development of chilling symptoms during cold storage of citrus fruits. J. Agric. Food Chem. 49: 6020-6025. DOI: 10.1021/jf010790b.

23. Hanson, K.R. and E.A. Havir, 1981. Phenylalanine Ammonia-Lyase. In: The Biochemistry of Plants, Secondary Plant Products, Stumpf, P.K. and E.E. Conn (Eds.). Academic Press, New York, USA., pp: 577-625.

24. Riov, J., S.P. Monselise and R.S Kahan, 1968. Ethylene-controlled induction of phenylalanine ammonia-lyase in citrus fruit peel. Plant Physiol., 44: 631-635.

http://www.pubmedcentral.nih.gov/articlerender.fc gi? artid=396138

25. Lafuente, M.T., L. Zacarias, M.A. Martínez-Téllez, M.T. Sánchez-Ballesta and A. Granell, 2003. Phenylalanine ammonia-lyase and ethylene in relation to chilling injury as affected by fruit age in citrus. Postharvest Biol. Technol., 29: 308-317. http://cat.inist.fr/?aModele $=$ afficheN\&cpsidt $=1519$ 5084
26. Tomás-Barberán, F.A. and J.C. Espín, 2001. Phenolic compounds and related enzymes as determinants of quality in fruits and vegetables. J. Sci. Food Agric., 81: 853-876. DOI: $10.1002 /$ jsfa.885

27. Pérez-Tello, G.O., M.A. Martínez-Téllez, B.O. Briceño, I. Vargas-Arispuro and J.C. Díaz-Pérez, 1999. Effect of Three Temperatures of Storage on the Activities of Poliphenoloxidase and Peroxidase in Mamey Sapote Fruits (Pouteria Sapota). In: AgriFood Quality II, Quality Management of Fruit and Vegetables, Hägg, M., R. Ahvenainen, A.M. Evers and K. Tiilikkala (Eds.). Woodhead Publishing Limited, Cambridge, UK., ISBN: 185573774 4, pp: 174-176.

28. Levitt, J., 1980. Responses of Plants to Environmental Stress. In: Chilling, Freezing and High Temperature Stresses, Academic Press, New York, USA., ISBN: 10: 0124455018, pp: 497.

29. King, A.I., D.C. Joyce and M.S. Reid, 1988. Role of carbohidrates in diurnal chilling sensitivity of tomato seedlings. Plant Physiol., 86: 764-768. http://www.pubmedcentral.nih.gov/articlerender.fc gi $\operatorname{artid}=1054566$

30. Holland, N., J.M. Sala, H.C. Menezes and M.T. Lafuente, 1999. Carbohydrates content and metabolism as related to maturity and chilling sensitivity of cv. Fortune mandarins. J. Agric. Food Chem., 47: 2513-2518. DOI: 10.1021/jf981402h

31. Saltveit, M.E., 2002. The rate of on leakage from chilling-sensitive tissue does not immediately increase upon exposure to chilling temperatures. Postharvest Biol. Technol., 26: 295-304. http://cat.inist.fr/?aModele $=$ afficheN\&cpsidt $=1398$ 5161 